\title{
Prognosis of Patients less than 40 Years of Age with Squamous Cell Cancer of the Oral Tongue
}

\author{
${ }^{1}$ Khalid Al-Qahtani, ${ }^{2}$ Valérie Brousseau, ${ }^{3}$ Tahera Islam
}

\begin{abstract}
Introduction: Controversy exists about the prognosis of squamous cell carcinoma of the tongue between young and older patients. Our objective was to evaluate age as a prognostic factor in oral tongue cancer.

Materials and methods: A retrospective study was conducted by reviewing charts of 61 patients. They were divided into two age groups, below 40 years and above 40 years. Data regarding epidemiology pathology report, tumor differentiation, staging, treatment and outcome were obtained. The length of survival and disease recurrence was calculated and compared in this two age group. Statistical analysis was performed using student, t-test.
\end{abstract}

Results: The result showed no significant difference in prognosis, tumor differentiation or staging related to age in oral tongue cancer.

Conclusion: Although age is not a significant prognostic factor in oral tongue cancer, the disease etiology is likely different, we recommend prompt and aggressive treatment of young patients.

Keywords: Disease recurrence, Length of survival, Prognostic factor, Tongue cancer, Tongue neoplasms.

How to cite this article: Al-Qahtani K, Brousseau V, Islam T. Prognosis of Patients less than 40 Years of Age with Squamous Cell Cancer of the Oral Tongue. Int J Head Neck Surg 2015;6(2): 53-56.

Source of support: Nil

Conflict of interest: None

\section{INTRODUCTION}

There has been a long-standing debate regarding the prognosis of young versus older patients affected with squamous cell tongue cancer. Some sources claim the prognosis of the young to be worse, ${ }^{1-5}$ others similar ${ }^{6-15}$ or better. ${ }^{16-18}$ Given the wide disagreement on the question, our study is unlikely to present an ultimate answer to this

\footnotetext{
${ }^{1,2}$ Consultant, ${ }^{3}$ Resident

${ }^{1}$ Department of Otolaryngology and Head and Neck Surgery, King Saud University, Riyadh, Saudi Arabia

${ }^{2}$ Department of Otolaryngology and Head and Neck Surgery McGill University Health Centre, Quebec, Canada

${ }^{3}$ College of Medicine and Research Center, King Saud University Riyadh, Saudi Arabia
}

Corresponding Author: Khalid Al-Qahtani, Consultant Department of Otolaryngology and Head and Neck Surgery King Saud University, Riyadh, Saudi Arabia, Phone: 00966114774136, e-mail: kqresearch@hotmail.com question. We nevertheless hope to be able to contribute to the understanding of this disease and evaluate our management by determining overall survival rate and disease-free survival in this series. In our opinion, prognostic factors are different in patients less than 40 . Because tumors behave more aggressively than suggested by their TNM staging in this age group, it has been shown that size of the lesion is not a good prognostic factor in oral cancer in this population. ${ }^{19}$ Furthermore, because epidemiological changes have taken place, notably a significant increase in oral cancer in women, ${ }^{20}$ we do not think that gender plays a significant prognostic role in the disease of young patients. We hope to be able to demonstrate our hypothesis through analysis of risk factors in this series.

\section{MATERIALS AND METHODS}

After approval by the McGill University Research and Ethics Committee, a list of all patients diagnosed with squamous cell cancer of the oral tongue in the 5 years from 2001 to 2006 was made from the records of the MUHC and Jewish General Hospital, Montréal, Canada. A total of 61 patients were identified. Charts were reviewed for gender, age at diagnosis, family history of head and neck cancer, smoking and alcohol consumption, presenting symptoms and findings at diagnosis, pathological report, surgery performed, radiotherapy received, complications, mortality and last date of follow-up. A database presenting details on prognostic and staging profile was developed using this information. In accord with previously published research, patients were stratified as less than or equal to 40 (young) or above 40 (older). Statistical analysis was performed using student t-test to determine significance.

\section{RESULTS}

Demographic analysis was made considering smoking, alcohol consumption and mortality (Table 1). Significant difference was only found in the incidence of smoking. In order to evaluate disease presentation, we evaluated the difference in stage (Table 2) and tumor grade at presentation (Table 3).

A total of 61 patients were found to have oral tongue cancer, among them 53 were older than 40 years of age 


\begin{tabular}{|c|c|c|c|}
\hline & Young $(<40)$ & Older $(>40)$ & $p$-value \\
\hline Number & 8 & 53 & \\
\hline $\mathrm{M} / \mathrm{F}$ & $6 / 2$ & $30 / 23$ & 0.28 \\
\hline Average age & $33(28-39)$ & $67(41-89)$ & \\
\hline Smoking & $1(13 \%)$ & $34(64 \%)$ & 0.007 \\
\hline Alcohol & $3(38 \%)$ & $22(42 \%)$ & 0.29 \\
\hline Mortality & $1(13 \%)$ & $3(5.6 \%)$ & 0.36 \\
\hline
\end{tabular}

Table 2: Stage at presentation per age group

\begin{tabular}{llll}
\hline Stages & Young $(<40)$ & Older $(>40)$ & $p$-value \\
\hline I & $2(25 \%)$ & $14(25 \%)$ & 0.33 \\
II & $1(12.5 \%)$ & $13(25 \%)$ & 0.30 \\
III & $3(38 \%)$ & $12(23 \%)$ & 0.21 \\
IV & $2(25 \%)$ & $14(26 \%)$ & 0.33 \\
\hline
\end{tabular}

Table 3: Tumor grade per age group

\begin{tabular}{llll}
\hline Grade & Young $(<40)$ & Older $(>40)$ & $p$-value \\
\hline Well & $3(38 \%)$ & $19(36 \%)$ & 0.30 \\
Moderate & $3(38 \%)$ & $18(34 \%)$ & 0.29 \\
Poor & $2(25 \%)$ & $16(30 \%)$ & 0.32 \\
\hline
\end{tabular}

and only eight of them were less than 40 years. Thirtyfour of the older age group (64\%) were smokers comparing to only one $(13 \%)$ of the younger age group. Similarly, alcohol consumption was more common in the older group $22(42 \%)$ in comparison to the younger age group $3(38 \%)$. The mortality was relatively higher in the younger age group (13\%) compared to $5.6 \%$ in older.

Most of patients, three (38\%) from the younger group, presented with stage III cancer while most of the patients $14(26 \%)$ from older group presented with stage IV. Histopathologically, well-differentiated, moderate and poorly differentiated cancers, all three were diagnosed almost equally in both groups (Table 3).

\section{DISCUSSION}

Several studies have previously attempted to compare the prognosis of patients less than 40 to those more than 40 affected with squamous cell tongue cancer. Unfortunately, no consensus has been reached in this debate as some concluded that the prognosis was worse, ${ }^{1-5,19}$ similar to, ${ }^{6-15}$ and others better ${ }^{16-18}$ in the younger population compared to older groups. Our study demonstrates a similar prognosis for both groups, the difference in mortality rate is insignificant with a p-value of 0.36 . This suggests that age is not a significant prognostic factor in this disease.

Our study demonstrates a similar prognosis for both groups, thereby suggesting that age is not a significant prognostic factor in this disease. However, given the relatively small number of patients studied, these findings should be considered against the light of the current literature, which remains ambivalent on the question.

Several studies have attempted to define the significant prognostic factors associated with squamous cell carcinoma of the tongue. Some of the factors identified include: male gender ${ }^{21,22}$ invasion of resection margins and smoking ${ }^{23}$ as well as tumor thickness and distance from resection margins. ${ }^{24}$ Furthermore, positive neck nodes are associated with a poor prognosis and low salvage rate. ${ }^{25}$ As with most other cancers, tumor (T) stage, nodal stage $(\mathrm{N})$ and extension to the tonsillar region were shown to have a significant relationship to survival, ${ }^{25}$ and perineural invasion to significantly increase the risk of recurrence. ${ }^{26}$ In this study, there was no significant difference in disease stage at presentation or tumor stage at resection between the older and the younger group. This thereby suggests that groups were relatively comparable regarding disease evolution and type between the two groups, enforcing the previously suggestion that there is indeed no significant difference in prognosis between older and younger patients, and this for equivalent disease stage or tumor grade.

Chewing betel nut or tobacco, smoking tobacco and alcohol abuse are all habits that have been identified as risk factors for the development of oral cancer. ${ }^{27-30}$ However, in most previous case series, patients with squamous cell tongue cancer less than 40 years of age tended to be nonsmokers and nondrinkers, $3,5,10,20,31-33$ which is also the case in this study. Even in cases where a significant number of young patients did drink or smoke $\mathrm{e}^{6,12,13,34}$ exposure time appears to be too short to be solely responsible for malignant transformation, making these factors less likely to play a significant role in the carcinogenesis of tongue lesions in young patients. This would thereby suggest that other etiologic factors, such as immune deficiency ${ }^{35,36}$ genetic factors, ${ }^{37}$ diet $^{38-40}$ or viruses, ${ }^{41,42}$ may be responsible for malignant transformation in the younger population. Hence because, prognosis is about the same between younger and older patients but disease etiology is unlikely to be the same, we recommend that young patients be assessed rapidly and be offered aggressive treatment.

\section{CONCLUSION}

The prognosis of younger and older patients has been the subject of much debate in the literature. Our study suggests that there is no significant prognostic difference between the two groups, but disease etiology is likely different, we recommend prompt and aggressive treatment of young patients. 


\section{REFERENCES}

1. Garavello W, Spreafico R, Gaini RM. Oral tongue cancer in young patients: a matched analysis. Oral Oncol 2007 Oct;43(9): 894-897.

2. Brägelmann J, Dagogo-Jack I, El Dinali M, Stricker T, Brown $\mathrm{CD}, \mathrm{Zuo} \mathrm{Z}$, Khattri A. Oral cavity tumors in younger patients show a poor prognosis and do not contain viral RNA Oral Oncol 2013 Jun;49(6):525-533.

3. Hilly O, Shkedy Y, Hod R, et al. Carcinoma of the oral tongue in patients younger than 30 years: comparison with patients older than 60 years. Oral Oncol 2013 Oct;49(10):987-990.

4. Soudry E, Preis M, Hod R, et al. Squamous cell carcinoma of the oral tongue in patients younger than 30 years: clinicopathologic features and outcome. Clin Otolaryngol 2010 Aug;35(4):307-312.

5. Jones J, Lampe H, Cheung H. Carcinoma of the tongue in young patients. J Otolaryngol 1989 Apr;18(3):105-108.

6. Friedlander PL, Schantz SP, Shaha AR, Yu G, Shah JP. Squamous cell carcinoma of the tongue in young patients: a matched pair analysis. Head Neck 1998 Aug;20(5):363-368.

7. Gilroy JS, Morris CG, Amdur RJ, Mendenhall WM. Impact of young age on prognosis for head and neck cancer: a matchedpair analysis. Head Neck 2005 Apr;27(4):269-273.

8. Mathew Iype E, Pandey M, Mathew A, et al. Squamous cell carcinoma of the tongue among young Indian adults. Neoplasia 2001 Jul-Aug;3(4):273-277.

9. Popovtzer A, Shpitzer T, Bahar G, Marshak G, Ulanovski D, Feinmesser R. Squamous cell carcinoma of the oral tongue in young patients. Laryngoscope 2004 May;114(5):915-917.

10. Cusumano R, Persky M. Squamous cell carcinoma of the oral cavity and oropharynx in young adults. Head Neck Surg 1988 Mar-Apr;10(4):229-234.

11. Pitman KT, Johnson JT, Wagner RL, Myers EN. Cancer of the tongue in patients less than forty. Head Neck 2000 May; 22(3):297-302.

12. McGregor G, Davis N, Robins R. Squamous cell carcinoma of the tongue an lower oral cavity in patients under 40 years of age. Am J Surg 1983 Jul;146(1):88-92.

13. Newman A, Rice D, Ossoff R, Sisson G. Carcinoma of the tongue in persons younger than 30 years of age. Arch Otolaryngol 1983 May;109(5):302-304.

14. Pytynia KB, Grant JR, Etzel CJ, Roberts D, Wei Q, Sturgis EM Matched analysis of survival in patients with squamous cell carcinoma of the head and neck diagnosed before and after 40 years of age. Arch Otolaryngol Head Neck Surg 2004 Jul; 130(7):869-873.

15. Chang TS, Chang CM, Ho HC, et al. Impact of young age on the prognosis for oral cancer: a population-based study in taiwan. PLoS One 2013 Sep 26;8(9):e75855.

16. Lee CC, Ho HC, Chen HL, Hsiao SH, Hwang JH, Hung SK. Squamous cell carcinoma of the oral tongue in young patients: a matched-pair analysis. Acta Otolaryngol 2007;127(11): 1214-1217.

17. Udeabor SE, Rana M, Wegener G, Gellrich NC, Eckardt AM. Squamous cell carcinoma of the oral cavity and the oropharynx in patients less than 40 years of age: a 20-year analysis. Head Neck Oncol 2012 May 30;4:28.

18. Annertz K, Anderson H, Biorklund A, et al. Incidence and survival of squamous cell carcinoma of the tongue in scandinavia, with special reference to young adults. Int J Cancer 2002 Sep 1;101(1):95-99.
19. Amsterdam JT, Strawitz JG. Squamous cell carcinoma of the oral cavity in young adults. J Surg Oncol 1982 Feb;19(2):65-68.

20. Patel SC, Carpenter WR, Tyree S, et al. Increasing incidence of oral tongue squamous cell carcinoma in young white women, age 18 to 44 years. J Clin Oncol 2011 Apr 10;29(11):1488-1494.

21. Pernot M, Malissard K, Hoffstetter S, et al. The study of tumoral, radiobiological and general health factors that influence results and complications in a series of 448 oral tongue carcinomas treated exclusively by irradiation. Int J Radiat Oncol Biol Phys 1994 July 1;29(4):673-679.

22. Mazeron JJ, Crook JM, Marinello G, Walop W, Pierquin B. Prognostic factors of local outcome for T1, T2 carcinomas of oral tongue treated by iridium 192 implantation. Int J Radiat Oncol Biol Phys 1990 Aug;19(2):281-285.

23. El-Husseiny G, Kandil A, Jamshed A, et al Squamous cell carcinoma of the oral tongue: an analysis of prognostic factors. Br J Oral Maxiollofac Surg 2000;38(3)193-199.

24. Al-Rajhi N, Khafaga Y, El-Husseiny J, et al. A early stage carcinoma of oral tongue: prognostic factors for local control and survival. Oral Oncol 2000 Nov;36(6):508-514.

25. Schroeff MP van der, Baatenburg de Jong RJ. Staging and prognosis in head and neck cancer. Oral Oncol 2009 Apr-May; 45(4-5):356-360.

26. O'Brien CJ, Lahr CJ, Soong S-J, et al. Surgical treatment of early-stage carcinoma of the oral tongue-would adjuvant treatment be beneficial? Head Neck Surg 1986 Jul-Aug;8(6): 401-408.

27. Radoï L, Paget-Bailly S, Cyr D, et al. Tobacco smoking, alcohol drinking and risk of oral cavity cancer by subsite: results of a French population-based case-control study, the ICARE study. Eur J Cancer Prev 2013 May;22(3):268-276.

28. Rosenquist K. Risk factors in oral and oropharyngeal squamous cell carcinoma: a population-based case-control study in southern Sweden. Swed Dent J Suppl 2005;179:1-66.

29. Petersen PE. Oral cancer prevention and control-the approach of the World Health Organization. Oral Oncol 2009 Apr-May;45(4-5):454-460.

30. Petti S. Lifestyle risk factors for oral cancer. Oral Oncol 2009 Apr-May;45(4-5):340-350.

31. Thomas L, Moore EJ, McGree ME, et al. Prognostic features, human papillomavirus status, and epidermal growth factor receptor expression in oral squamous cell carcinoma in young adults. Am J Otolaryngol 2012 Nov-Dec;33(6):650-656.

32. Verschuur HP, Irish JC, O'Sullivan B, Goh C, Gullane PJ, Pintilie M. A matched control study of treatment outcome in young patients with squamous cell carcinoma of the head and neck. Laryngoscope 1999;109(2 Pt 1):249-258.

33. Salem A Dismissing links between HPV and aggressive tongue cancer in young patients. Ann Oncol 2010 Jan;21(1):13-17.

34. Llewellyn CD, Linklater K, Bell J, Warnakulasuriya S. An analysis of risk factors for oral cancer in young people: a case-control study. Oral Oncol 2004 Mar;40(3):304-313.

35. Freiser ME, Serafini P, Weed DT. The immune system and head and neck squamous cell carcinoma: from carcinogenesis to new therapeutic opportunities Immunol Res 2013 Nov 12.

36. Badoual C, Sandoval F, Pere H, et al. Better understanding tumor-host interaction in head and neck cancer to improve the design and development of immunotherapeutic strategies. Head Neck 2010;32(7):946-958.

37. Deshpande AM, Wong DT. Molecular mechanisms of head and neck cancer. Expert Rev Anticancer Ther 2008 May;8(5): 799-809. 
38. De Stefani E, Boffetta P, Ronco AL, et al. Dietary patterns and risk of cancer of the oral cavity and pharynx in Uruguay. Nutrition and Cancer 2005;51(2):132-139.

39. Bradshaw PT, Siega-Riz AM, Campbell M, Weissler MC, Funkhouser WK, Olshan AF. Associations between dietary patterns and head and neck cancer: the carolina head and neck cancer epidemiology study. Am J Epidemiol 2012 Jun 15;175(12):1225-1233.

40. Chuang SC, Jenab M, Heck JE, Bosetti C, Talamini R, Matsuo $\mathrm{K}$, et al. Diet and the risk of head and neck cancer: a pooled analysis in the INHANCE Consortium Cancer Causes Control 2012 Jan;23(1):69-88.

41. Miller DL, Puricelli MD, Stack MS. Virology and molecular pathogenesis of HPV (human papillomavirus)-associated oropharyngeal squamous cell carcinoma. Biochem J 2012 Apr 15;443(2):339-353.

42. Allen CT, Lewis JS Jr, El-Mofty SK, Haughey BH, Nussenbaum B. Human papillomavirus and oropharynx cancer: biology, detection and clinical implications. Laryngoscope 2010 Sep; 120(9):1756-1772. 